\title{
Rock art and rock music: Petroglyphs of the south Indian Neolithic
}

\author{
Nicole Boivin ${ }^{1}$
}

The rock art of Kupgal, south India, represents an archive of images amassed over five millennia. The author works out a first sequence and shows how the Neolithic petroglyph site may have functioned in its landscape - as a ritual locality at which not only images but sound, performance and social relationships were all prominent.

Keywords: Neolithic, India, rock art, gender, music, landscape

\section{Rock art studies in India}

Rock art in South Asia exhibits a wide geographical and chronological distribution. Petroglyphs and pictographs on natural stone surfaces are found across the subcontinent, and date from the Palaeolithic period through to the present day (Bednarik 1993, 2002; Brooks \& Wakankar 1976; Chakrabarti 1999; Chakravarty \& Bednarik 1997; Neumayer 1983). Nonetheless, South Asia has been largely overlooked in more recent studies that have sought a more theoretically-informed and interpretative approach to rock art (e.g. Chippindale \& Taçon 1998; Goldhahn 1999; Helskog \& Olsen 1995; Whitley 2001). In keeping with patterns in other realms of archaeological study in the subcontinent (see Boivin \& Fuller 2002; Fuller \& Boivin 2002), the study of rock art in South Asia remains largely descriptive and theoretically uninformed.

As such, rock art studies in South Asia have generally failed to contribute significantly to an understanding of the South Asian past, or of rock art production in general. This preliminary study offers an attempt to demonstrate the benefits of moving beyond a purely descriptive and image-focused approach to rock art in South Asia. An associated aim is the generation of interest in rock art traditions, both past and present, that are threatened by economic and social transformations currently underway in the region. South Asia badly needs scholars to study and record both ongoing rock art traditions and the remains of past rock art practices in the face of unprecedented social change and site destruction.

\section{The south Indian Neolithic}

This study will focus in particular on the rock art of the Neolithic period of south India, and specifically the site of Kupgal in Karnataka (see Figure 1). Although it is later in date than the proto-Harappan Neolithic of the Indo-Iranian border region (dating from the early third to

1 The McDonald Institute for Archaeological Research, University of Cambridge, Downing Street, Cambridge CB2 3DZ, UK (Email: nlb20@cam.ac.uk) 


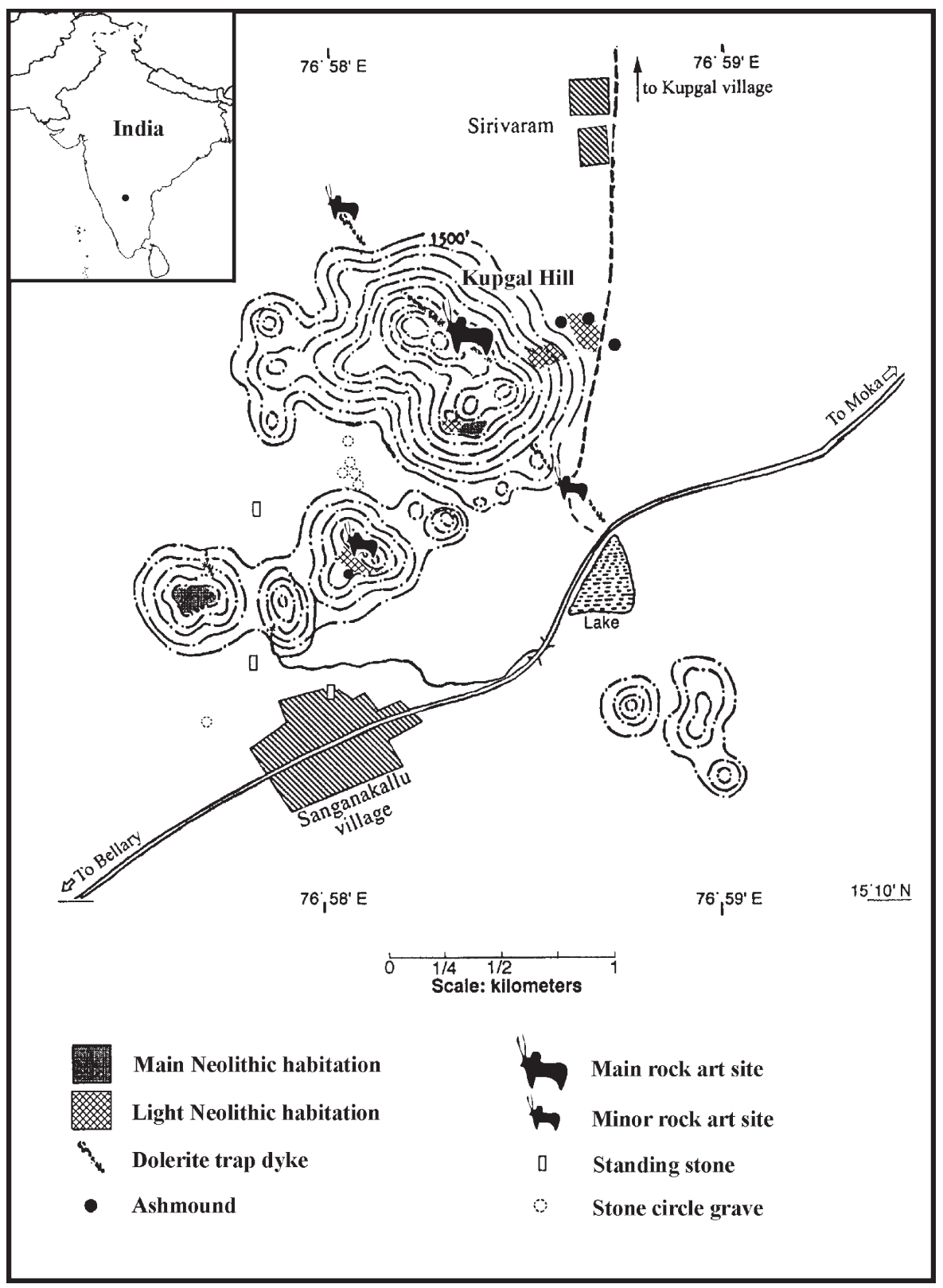

Figure 1 Map of the Sanganakallu-Kupgal heritage area, showing locations of main prehistoric sites (adapted from Figure 5.8 in Fuller 1999).

first millennium BC, the south Indian Neolithic actually overlaps with the Mature phase of the Harappan Civilisation), the Neolithic of south India may in some ways be considered of greater interest than this latter period. This is because, in contrast to the Neolithic of Baluchistan and eastern Afghanistan, which has much in common with the Neolithic of neighbouring South-west Asia (Allchin \& Allchin 1982; Piggott 1950), it features a 
distinctively Indian, and probably independently domesticated crop package (Fuller 1999, in press, forthcoming; Fuller et al. 2001), a distinctively Indian emphasis on cattle pastoralism (Allchin 1963; Korisettar et al. 2001; Paddayya 1998; Paddayya et al. 1995), and a distinctively Indian form of ritual involving the burning of large quantities of cowdung (Zeuner 1960; Allchin 1963). The latter is a particularly unique feature of the south Indian Neolithic, and resulted in the formation of large 'ashmounds' up to 30 feet high at specific places in the landscape.

Despite the obvious richness of the south Indian Neolithic, this archaeological entity has received surprisingly little sustained attention from South Asian archaeologists. Raymond Allchin's Neolithic Cattle-Keepers of South India, published in 1963, remains the major synthetic work on this period. Recent years have, however, seen somewhat of an upsurge in interest in the Southern Neolithic (as it is known within India), with the launching of a number of new excavation and survey projects aimed at systematically addressing particular questions concerning the origins and development of the Neolithic in the central Deccan (Devaraj et al. 1995; DuFresne et al. 1998; Fuller 1999, in press, forthcoming; Fuller et al. 2000-2001, 2001; Korisettar et al. 2001; Paddayya 1993, 1998; Paddayya et al. 1995).

In 2002, I initiated one such project, in collaboration with Ravi Korisettar of Karnatak University (Boivin forthcoming; Boivin et al. 2002, 2003 and forthcoming). As one small component of this project, I made a preliminary investigation of some of the rock art associated with the south Indian Neolithic. This survey was impressionistic rather than systematic, and the findings discussed here should thus be regarded as tentative and subject to amendment. Nonetheless, a preliminary discussion of these findings was considered justified in light of the fact that so little has been written on the prehistoric rock art of south India (Neumayer 1983), despite its ubiquity and clear relevance to our understanding of the society or societies that produced it. Discussions of south Indian rock art have largely been relegated to short papers or brief summaries within excavation reports (Allchin 1960, 1963; Ganapayya Bhat 1981; Foote 1979, Gordon 1951; Gordon \& Allchin 1955; Nagaraja Rao \& Malhotra 1965; Neumayer 1983; Paddayya 1973; Rami Reddy 1971; Subbarao 1947), most of which focus simply on describing the images (though see Allchin \& Allchin 1994-95).

\section{Dating south Indian rock art}

Most researchers who address south Indian rock art highlight the fact that its dating is problematic (Allchin 1960; Allchin \& Allchin 1994-95; Chandramouli 1991; Ganapayya Bhat 1981; Gordon 1951; Paddayya 1973). Nonetheless, development of a preliminary and very rough chronological sequence for the rock art of south India has been enabled through the integration of various strands of evidence, including consideration of artistic style and method, rock art content, and proximity to archaeological sites of known periods (see in particular Allchin \& Allchin 1994-95).

Such work suggests that Neolithic rock art can be distinguished from rock art of other periods based on its distinctive style, subjects, method of production and weathering characteristics, and the repeated association of these features with archaeological sites of the Neolithic period (Chandramouli 1991; Gordon \& Allchin 1955; Allchin \& Allchin 199495; Nagaraja Rao \& Malhotra 1965). However, it should be stressed that this work has not reached a very advanced stage, and thus the dating of images remains insecure. Systematic 
studies towards the production of rock art chronologies, and, if possible, the application of scientific dating methods, are advances that are clearly needed in south India.

\section{The site: Kupgal and its rock art}

The site that I will mainly focus on in the present discussion is situated in Bellary district of mid-eastern Karnataka. Located approximately $5 \mathrm{~km}$ north-east of the town of Bellary is an outcrop of granitic hills of various sizes, upon and around which are concentrated various remains of the prehistoric and historic periods (see Figure 1). Archaeological sites in this area appear in the literature under various guises, but Sanganakallu and Kupgal, the names of two local villages, are common referents. I thus use the term Sanganakallu-Kupgal to refer to the complex of hills and sites (see Boivin et al. 2002). The Sanganakallu-Kupgal prehistoric heritage area was clearly a very significant locale during the Neolithic period, as evidenced by the wealth of sites and finds that have been discovered and investigated here, beginning as early as the 1800s (Allchin 1963; Ansari \& Rao 1969; Foote 1887a, 1887b, 1895; Mujumdar \& Rajaguru 1966; Subbarao 1947, 1948). Neolithic remains are concentrated on the tops and slopes of the granite hills, while remains of the Megalithic (Iron Age) and Early Historic, and subsequent periods focus predominantly on the immediately surrounding peneplain.

The major rock art site at Sanganakallu-Kupgal is located on the largest and northernmost of the granitic hills (see Figure 1). The British named the hill Peacock Hill during the colonial period, and it is sometimes referred to as such in the early literature (e.g. Foote 1887, 1895). Locals, generally call the hill Hiregudda, which simply means 'Big Hill'. Most archaeological literature, however, refers to the hill as Kupgal Hill, after a neighbouring village, and thus, for the sake of continuity (if not accuracy) I will maintain this usage (the nearest village is actually Sirivaram). Kupgal Hill is a substantial granitic hill with several peaks that is traversed along its axis by a large dolerite trap dyke. Petroglyphs of various periods, from the Neolithic to the modern-day, are found bruised or engraved on the black rocks all along the dyke, but in particular there is a heavy concentration of art where the dyke emerges across the upper northern peak of the hill (see Figure 1).

The first report on the petroglyphs at Kupgal seems to have appeared in 1892, in the Asiatic Quarterly Review (Fawcett 1892). The brief summary by Fawcett, is accompanied by hand sketches produced by Sewell. Foote also briefly addressed the Kupgal rock art in his 1916 volume on the Prehistoric and Protohistoric Antiquities of India (Foote 1979). Subsequently, archaeologists seem to have had trouble re-locating the rock art described in these reports. Subbarao writes that Longhurst apparently could not find the petroglyphs during a visit to the site in 1913, and thus believed them destroyed (Subbarao 1947), while the map and comments in Subbarao's 1947 report indicate that he himself never found the main rock art site at the top of Kupgal Hill. The next report on the Kupgal rock art is produced in 1951 by Gordon, who never actually visited the site. Paddayya also briefly mentions the Kupgal rock art in a 1973 report, but it is clear that he too missed the main rock art site. Since this there has been silence.

Only a few photographs of the Kupgal rock art have ever been published. Photographs of the site, apparently taken by Fawcett (Subbarao 1947) were sent to the Madras Museum and the Royal Anthropological Institute (Gordon 1951). Although the photos in the Madras Museum were apparently lost or allowed to fade (Gordon 1951; Subbarao 1947), those in 
the R.A.I. were re-photographed before they faded, and a few were later published by Gordon (1951). Thus, this is only the second time that photographs of the Kupgal rock art have ever been published, despite the fact that the site contains a very substantial array and quantity of rock art.

\section{The images at Kupgal}

Although no attempt has ever been made to quantify the amount of rock art at Kupgal Hill, it is clear that the dolerite trap dyke contains hundreds and perhaps even upwards of a thousand individual images and scenes. All the images are petroglyphs (mostly "bruisings"), though pictographs can be found, much more rarely, on granite boulders at other locales in the SanganakalluKupgal area (the rarity of pictographs may be due to taphonomic factors; see Allchin 1960 and Neumayer 1983).

The primary subject matter of most of the Kupgal Hill rock art, including main and subsidiary sites along the trap dyke, is cattle, of the long-horned, humped back variety (Bos indicus) that is common in south India today (see Figure 2). The cattle appear as single images, and, less commonly, in scenes that depict, for example, two cattle facing each other, cattle being ridden by anthropomorphic figures, or cattle surrounded

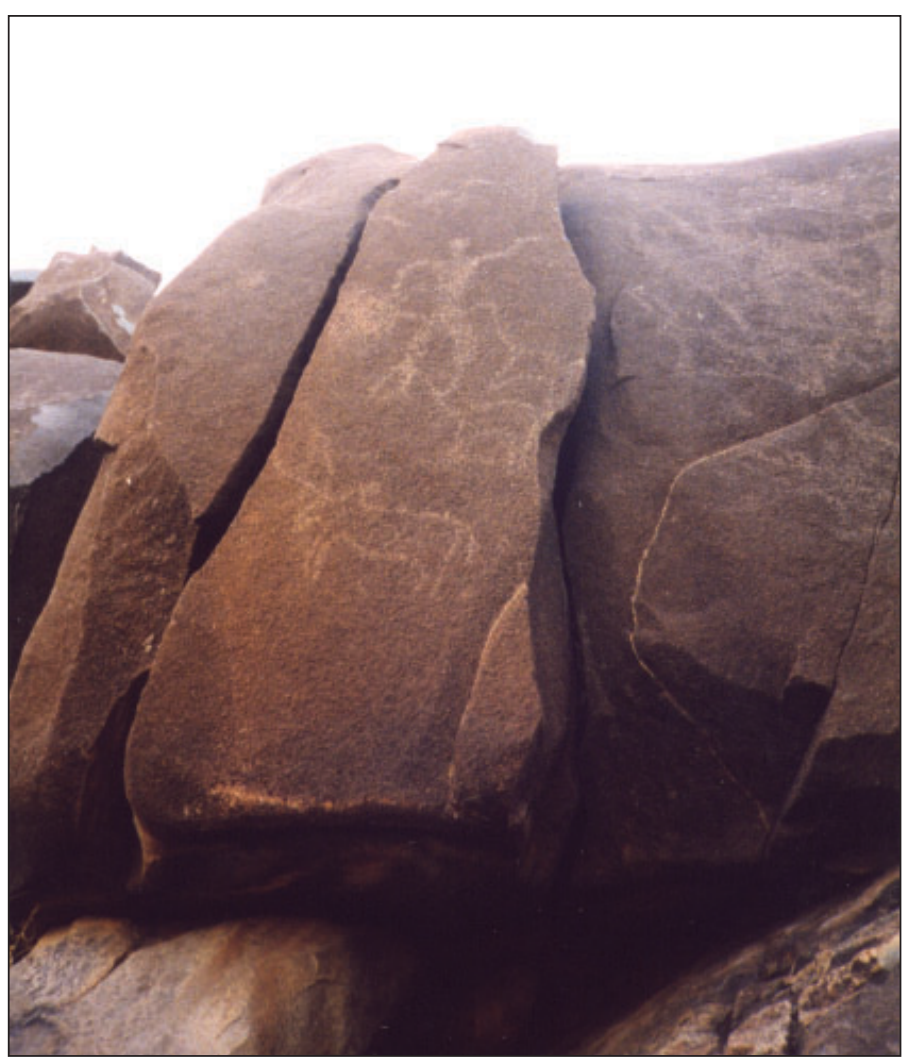

Figure 2 Cattle and anthropomorphic figures bruised onto rock face, main rock art site, Kupgal Hill

by anthropomorphic figures, some holding bows and arrows (apparently representing cattle being hunted or perhaps captured). In single images, cattle are sometimes depicted atop 'tridents' or bearing three rather than two horns. In a number of cases, cattle are shown with male genitalia.

After cattle, the next most common motif is the anthropomorphic figure (see Figures 2 and 3). Many of the figures are ithyphallic and hence apparently male, and scenes of sexual intercourse (involving male and female figures and sometimes possibly animals) are relatively common. These images were generally referred to as 'obscene' by earlier commentators, who 


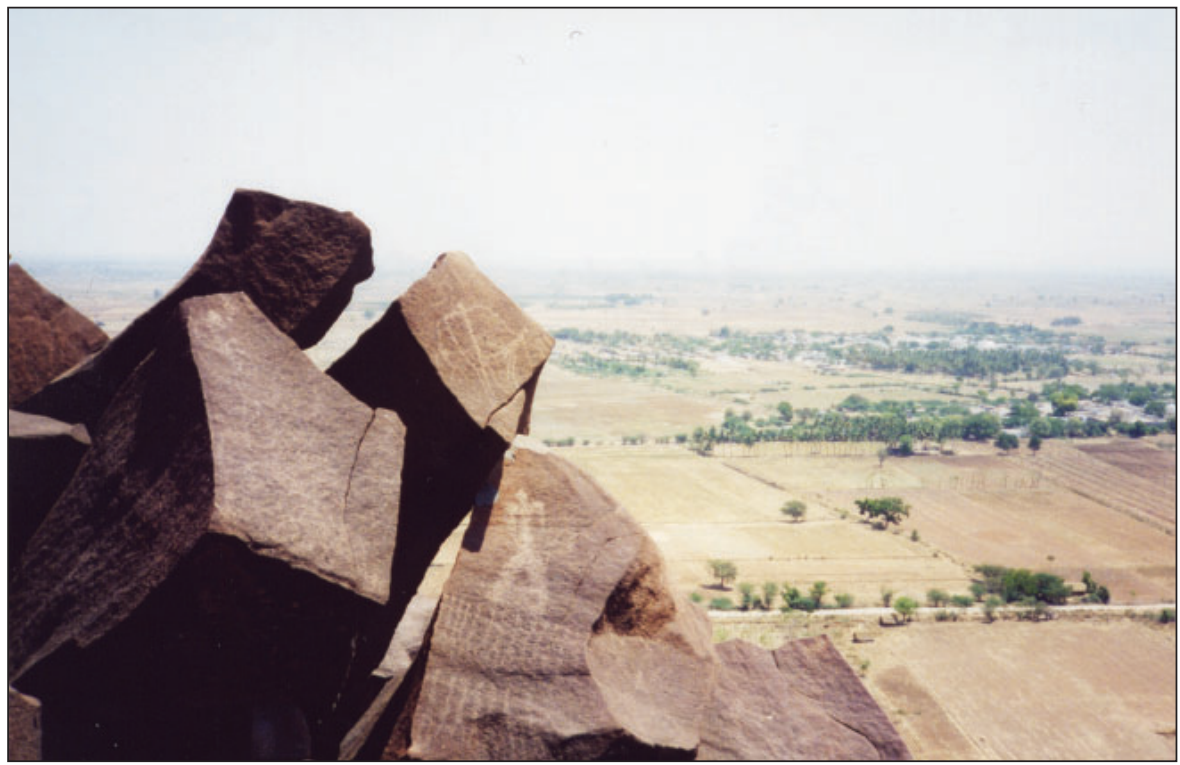

Figure 3 Rocks bearing various overlapping motifs at the main petroglyph site at Kupgal Hill. Some anthropomorphic figures are in chains, while others appear to be engaged in sexual activity.

nonetheless dutifully reported on the more 'lurid' details. For example, Gordon writes of one image of an apparent 'abduction', showing " a man, whose intentions cannot very well be mistaken, gripping a woman by the hair" (Gordon 1951: 117). Anthropomorphic figures are also shown using bows and arrows (probably hunting), raiding(?) cattle, and riding animals. In some cases, figures are arranged in long chains which are generally interpreted in the literature as dancing figures.

Relative to cattle and humans, other motifs and subjects are much less frequently depicted. These include what appear to be elephants, tigers, deer, buffalo, birds and other animals, as well as abstract motifs (cup-marks, rows of dots, 'ladders', etc.), religious symbols, footprints and, in at least one case, a probable cart. In general, the rock art is dominated by single, apparently unrelated motifs, and small simple scenes. Large, complex narrative scenes appear to be absent, though big boulders sometimes bear substantial accumulations of closely arranged, often superimposed individual images and scenes.

\section{Kupgal chronology}

As indicated, the Kupgal Hill petroglyphs do not represent a single period, but rather seem to cover a whole range of periods, from prehistory into the historical period (Fawcett 1892; Gordon 1951). Indeed, rock art continues to be produced today on the dyke and at other locales in the Sanganakallu-Kupgal area (see Figure 6). A thorough analysis of the chronology of the Kupgal rock art is desperately needed, and the preliminary outline that I sketch here is only a start. Nonetheless, it seems possible to place a good number of the images into a very general chronological scheme (which I briefly summarise in Table 1), based on differences of style, content and location. 
Table 1 Chronological sequence of Kupgal Hill rock art

\begin{tabular}{ll}
\hline Period & Types of images/scenes represented \\
\hline Neolithic & $\begin{array}{l}\text { naturalistic cattle, ithyphallic figures, sexual scenes, 'dancing' } \\
\text { anthropomorphic figures } \\
\text { crude cattle, horses, anthropomorphic figures }\end{array}$ \\
Megalithic & $\begin{array}{l}\text { crude cattle, elephants, horses, anthropomorphic figures, writing (Kanada } \\
\text { alphabet) } \\
\text { religious symbols (Muslim, Hindu), hearts with arrow, writing (Kanada, } \\
\text { Modern } \\
\text { Roman alphabets), worship-related symbols, anthropomorphic figures, } \\
\text { snakes, peacocks }\end{array}$ \\
\hline
\end{tabular}

Rock art was attributed to the Neolithic period based on various strands of evidence. Naturalistic and elegantly drawn cattle similar to cattle images found at other Neolithic sites could be distinguished from crudely drawn, more rectilinearly shaped cattle not just on the basis of style (see also Allchin 1960; Allchin \& Allchin 1994-95; Gordon \& Allchin 1955), but also as a result of differences in location and clarity. Naturalistic cattle are concentrated on the top of Kupgal Hill, and especially on vertical rock faces that are more difficult to access. More crudely drawn cattle, and other motifs of definite post-Neolithic date, such as the cart depiction, as well as elephants, religious symbols and modern graffiti are focused more on the trap dyke where it emerges from the base of the hill to the south-east and northwest, and on easy-to-access horizontal stone surfaces on the upper trap dyke exposure. These differences also coincided with differences in the clarity of the images; the latter rock art images are much more clear and defined than the former. Whether this has to do with method of production or the effects of weathering is, however, presently unclear.

By using these various clues, and referencing the available literature on south Indian rock art, it was possible to build up a tentative chronology, and to identify rock art of probable Neolithic date from amongst the images present. Aside from the naturalistic cattle, I also attribute many of the iphythallic figures and sexual scenes to the Neolithic period. Many of the cattle-related scenes on vertical rock faces on the upper dolerite outcrop, including cattleriding and possible cattle-raiding scenes are also probably Neolithic as well. Other scenes and motifs are more problematic. It is difficult, for example, to date the abstract motifs that appear mainly on the lower eastern outcrop, though these may also be Neolithic. Overall, I feel that much of the rock art on the upper outcrop is Neolithic, especially on the more difficult-to-access vertical faces below the peak, while later rock art seems to concentrate more on the outcrops at the base of the hill.

\section{The Kupgal Neolithic rock art in context}

While traditional discussions of rock art tended to focus on its pictorial content, many recent ethnohistorical and archaeological studies have emphasised also the importance of context (e.g. Bradley 1997, 2000; Chippindale \& Taçon 1998; Goldhahn 2002; Hedges 1993; Taçon 1990). These studies have looked beyond the images themselves, to an examination of their placement in the wider landscape, and their association with particular features and types of stone, for example. Such an approach has only very rarely been applied in India, but 
preliminary assessment suggests that it might provide insights into the Neolithic production of rock art at Kupgal Hill.

As I have already indicated, the Neolithic rock art on the upper dolerite dyke at Kupgal is often located on vertical rock faces below the peak of the hill. These areas can be somewhat difficult to access, as reaching them involves climbing the jagged boulders of the dolerite outcrop, which form a cliff suspended high above the surrounding terrain (see Figures 3 and 4). This is not art for those with a fear of heights. Both those who viewed the motifs, and, in particular, those who produced them would have had to possess a reasonable

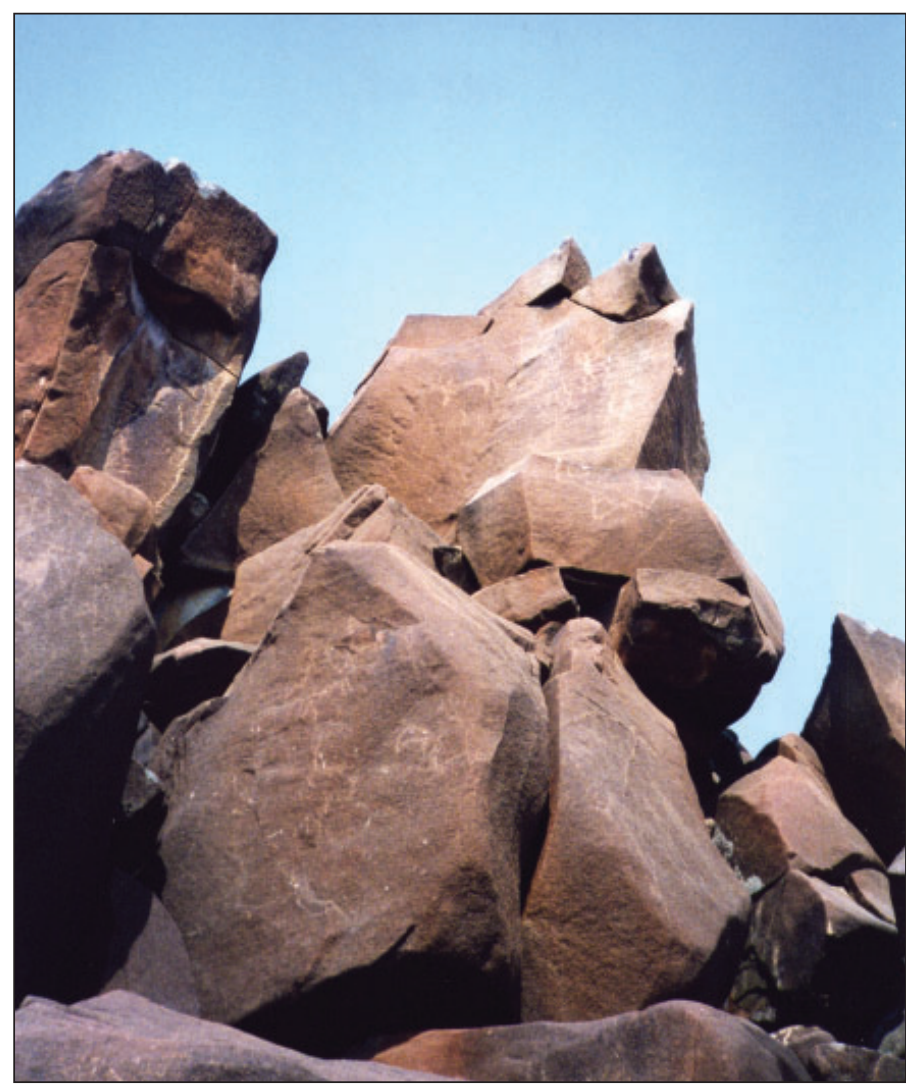

Figure 4 The jagged rocks at the main Kupgal rock art site. Rock art motifs like the bull motif on the upper right-hand stone are difficult to access and view. degree of physical fitness and agility. In some cases, images are in locations so difficult to reach that we must assume that the artist who produced them was also quite athletic, being required to suspend him or herself from some overhang for the time it took to create the image (such individuals may also have relied on assistance from others).

In addition, it is interesting that the nature of the rocky terrain would in the majority of cases have permitted only a few people at most to view a given image at any one time. Not only are spaces small on the dolerite outcrop, but the jagged rocks interrupt lines of view, constraining the number of vantage points from which images can be seen. This factor, which quickly becomes evident if too large a group tours the rock art together, suggests that what we must envision are artists and viewers alone or in small groups on the dolerite outcrop.

What begins to emerge then is a picture of exclusivity, whereby not all members of society are equally involved in the production and consumption of the art. Indeed, participation in the activities surrounding the rock art may have been limited to a particular sector of society. Given the nature of the images, which seem in part to celebrate male prowess and male sexuality, as well as links between men and cattle, one possibility is that rock art activities at Kupgal were carried out predominantly by men. Both the images and the difficulty of the terrain suggest that these would have been younger rather than older men, perhaps those 
who were associated with the herding of cattle, and even their theft from other groups. Cattle raiding has been an ongoing theme in South Asian rural societies since at least the protohistoric era, as documented in ancient texts like the Rig Veda, and evidenced in the pan-continental distribution of 'hero stones', which commonly commemorate individuals killed whilst protecting cattle herds during raids (see O'Flaherty 1994; Settar \& Sontheimer 1982; Thapar 1981).

Interestingly, a link between the rock art locale and young men is found today in the area. The upper Kupgal Hill rock art site is currently associated with the god Pitlappa, who is worshipped in a small painted alcove that sits amidst the ancient petroglyphs. During the annual Pitlappa puja (worship) in August, people from the nearby villages come to Kupgal Hill, but most remain at the base of the hill, where a ceremony involving music and offerings is conducted. Only a small group of young men and boys make the journey all the way to the top of the hill to worship at the painted alcove.

Perhaps even more revealing is the link between rock art and the production of lithics at Kupgal. Apart from being one of south India's most outstanding surviving rock art sites, Kupgal Hill is also the location of a major Neolithic stone quarrying and tool production centre. Across much of the north-eastern slope and top of the hill, and especially where there is disturbance as a result of modern day granite quarrying, there can be found today a dense scatter of debitage and unfinished Neolithic tools. It is clear that the quarrying of dolerite, and production of tools from this material was carried out at the site on a significant scale over a substantial period of time, and most probably involved the temporary settlement of groups from other areas.

These tool-related activities may also link men to the dolerite outcrop and its rock art. While it would certainly be inaccurate to suggest that only men made stone tools in Neolithic south India (Gero 1991; Sassaman 1998), it is possible to hypothesise that, as in many ethnographic contexts, it was primarily men who were involved in the collection or quarrying of raw stone as well as the production of standardised, highly elaborated stone tools outside the domestic context (Burton 1984; Gero 1991; Jones \& White 1988; Sassaman 1998; Sillitoe \& Hardy 2003; Taçon 1991). The dolerite trap dyke would have been visited by men for quarrying purposes, and they may then have fashioned the highly polished stone axes that are often associated with Neolithic sites in south India and undoubtedly held symbolic as well as economic value. These are frequently made of dolerite, and their production involves a number of time-consuming and elaborate steps.

These dolerite axes may have contrasted with the granite rubber stones, querns and circular grinding hollows that are ubiquitous on south Indian Neolithic settlements, since these plant processing tools were likely strongly associated with women and their work, and must certainly, in some cases at least, have been produced by them as well. That there may thus have been an association between dolerite and men, and granite and women is interesting to postulate, especially since the only example of Neolithic rock art in a domestic context that I have seen in the southern Deccan (at Velpumadugu, depicting a peacock) was an engraving on granite. Also symbolically suggestive is the fact that the dolerite trap penetrates into the surrounding granite rock, and that its black colour contrasts sharply with the soft pink of the granite; pink and red are today associated with women in many parts of the world, including India (Beck 1964; Boivin 2001). 
It is interesting to speculate that the durable, possibly male-oriented rock art in nonsettlement contexts discussed here was accompanied during the Neolithic by a female-centred, non-durable tradition of domestic art, as is found in contemporary rural India to this day (Bagwe 1995; Boivin 2000, 2001; Huyler 1995; Leslie 1991; Nagarajan 1995). Village women across India create artistic designs on the walls and floors of their homes by painting, plastering and moulding out of mud, but this art does not so effectively withstand the effects of time (Boivin 2001). The peacock petroglyph at Velpumadugu may represent a rare durable example of such domestic art in the prehistoric context.

\section{Rock art and ritual}

In addition to examining who may have been involved in creating and consuming the Kupgal Neolithic period rock art, we may also use contextual information to explore the question of when the rock art may have been produced. If specific groups were visiting the rock art site to add further images during the Neolithic, when were they doing so and what was their purpose? Several strands of evidence suggest that their visits were probably formalised, and part of larger ritual events in which a wider cross-section of society participated.

One suggestive discovery made during the 2002 field season was that some of the dolerite boulders at the upper Kupgal rock art site appear to have been used for percussion purposes. These boulders, which were referred to as 'musical stones' by Ramadas, one of our local guides, bear multiple small groove-like impressions. As Ramadas demonstrated, these impressions emit loud

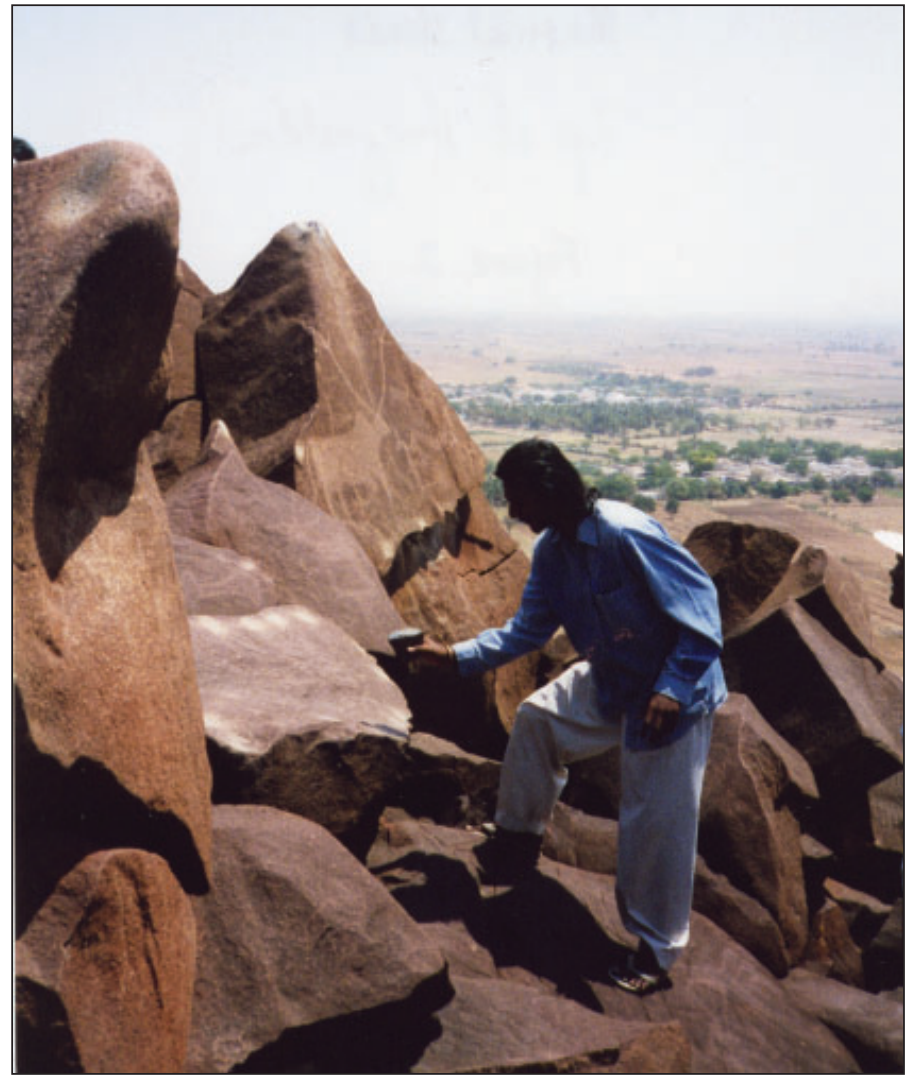

Figure 5 Ramadas demonstrating how to elicit bell tones from 'ringing rocks' at Kupgal Hill by striking them with a granite stone. Note the rounded grooves produced on many of the rocks shown in the photograph due to this kind of activity. musical ringing tones when struck by granite stones (see Figure 5). The production of these deep bell- or gong-like sounds occurs only when the rounded impressions are struck, and not when other parts of the boulders are hit. Similar rounded impressions or 'ringing rocks' as 


\section{Nicole Boivin}

such stones are commonly termed in other parts of the world, were subsequently found at other rock art sites in the vicinity, including the dolerite outcrop to the west of Halakundi.

The use of boulders as percussive instruments has been documented in other regional contexts, sometimes in association with rock art. For example, shale boulders at Ringing Rocks State Park in Pennsylvania, USA are covered in bowl-shaped indentations produced by striking the rocks with stones or hammers to create musical ringing tones (Milne 1995). Diffuse and concentrated clouds of hammer marks have been found on stones at an important rock-engraving locale in the north-west Province of South Africa, and identified as the residue of certain San rituals at which the production of percussive sound such as hammering and drumming was required (Ouzman 1998: 38; 2001). Examples of rock art occurring in direct association with rocks that ring like a chime when struck have also been documented at multiple sites in the American far west (Hedges 1993), and in Oceania (Rainbird 2002a, 2002b).

The importance of music in general, and percussion in particular, in various ritual transformations across the world has been noted by numerous researchers (Needham 1967; Tuzin 1984). Percussion appears to play a role in effecting transformations in shamans or other ritual participants, sometimes allowing them to communicate with the supernatural world (Needham 1967). In rural Rajasthan, for example, spirit possession of shamans (bhopa) is preceded by the measured beating of large, loud drums (Boivin 2001: 26). Links between percussion and rituals related to rock art have been ethnographically documented or archaeologically postulated in a number of cases (Hedges 1993; Ouzman 1998, 2001), and it may be that percussion and/or other sounds contribute to the creation of an appropriate spiritual or emotional state for the viewing or creation of rock art in ritual contexts (Goldhahn 2002; Ouzman 1998; Scarre 1989).

Although it is of course difficult, if not impossible, to date the grooved impressions on the dolerite boulders at Kupgal and other sites, their repeated association with rock art of Neolithic date is certainly suggestive. Ethnographic and archaeological analogues allow us to speculate that the creation and/or consumption of rock art images at Kupgal may have been associated with the production of particular meaningful, powerful and possibly musical sounds in the context of certain ritual performances. The main rock art site at Kupgal may have been a place where 'shaman'-like individuals or some other particular group within Neolithic society, such as male cattle herders or young male initiates, went to carry out particular rituals and/ or tap into the power of the site (see below). The rock art itself is suggestive of a ritual interpretation, since the individual floating images and simple scenes in difficult-to-access places seem to be aimed less at recording particular historical events for wide consumption than conveying esoteric information to individuals or small parties.

That the Kupgal rock art site was associated with rituals of some sort is also supported by its spatial relationship to the Neolithic ashmounds that once stood at the base of the hill (see Figure 1). Although only one is still extant, the remains of two others which have recently been destroyed can also be seen, and the rock art site offers superb views of all three. Whether others may have once existed is difficult to clarify, but the presence of even three together in one place, if we accept the convincing evidence that they are, at least in part, places of ritual (see Allchin 1963; Boivin forthcoming; Korisettar et al 2001), is strongly suggestive of an important ritual role for the ashmounds and the rock art that overlooks them, given that ashmounds more normally occur singly (Korisettar et al. 2001: 210). 
That the site itself may have held sacred or mythical importance is also suggested by the presence of a visually stunning granite cliff at the top of the Kupgal peak that rises just behind the site of the ashmounds. In addition, the ashmounds and rock art are located on the east side of Kupgal Hill, and there is some (still preliminary) evidence that the east held meaningful, perhaps sacred connotations during the Neolithic period (Boivin forthcoming). These spatial features, combined with the presence of a major stone tool quarry, suggest that Kupgal may have acquired sacred or mythical attributes during the Neolithic period, which may have made it an important site for the performance of certain rituals. That stone tool quarries, especially those located in inaccessible or visually stunning locales, often had important symbolic or sacred connotations has been argued by Bradley and Edmonds (Bradley 2000; Bradley \& Edmonds 1993), as well as Taçon (1991), for example.

The nature of these rituals is of course difficult to reconstruct, though the evidence that they were in some way related to cattle is overwhelming. Allchin used ethnographic parallels to modern-day pastoral groups and rituals involving the burning of cowdung to suggest that the ashmounds may have been implicated in rituals relating to fertility and the protection of cattle (Allchin 1963). The rock art motifs seem to echo a concern for cattle and fertility. In a society where cattle held clear symbolic as well as economic importance (Allchin 1963; Korisettar et al. 2001; Paddayya 1993, 1998; Paddayya et al. 1995), such concerns would certainly not be out of place.

These shared themes and the spatial relationship between the rock art and ashmound sites suggest that the activities at the two locales mutually informed each other. That these activities were, at least on some occasions, ritual in nature seems likely. It may be that Kupgal Hill held special significance, and was the focus for large-scale ritual events. Some of these may have been participated in by diverse elements of society, while others, such as perhaps those that took place at the less easily accessible rock art site on the dolerite cliff, may have been restricted to particular individuals or groups.

The existence of a child burial in the ashmound at Utnur has been taken to suggest that not just men, but also women and children undertook movement with herds during the Neolithic (Allchin 1963; Fuller 1999; Korisettar et al. 2001), and it may be that ashmound rituals or ceremonies were open events involving all elements of society. The rituals at the rock art site above, however, may have involved a particular sub-group splitting off to engage in more esoteric pursuits. The depiction of an anthropomorphic bull creature apparently garbed in a long robe at the Kupgal Hill main petroglyph site may represent a ritual specialist with supernatural powers, for example. These rituals may have placed more emphasis on the relationship between men and cattle than did the hypothesised more general fertility/ prophylactic rituals on the plain below. They may represent a shift from an essentially egalitarian society to one in which divisions based on age and gender were becoming increasingly important.

\section{Conclusion}

The interpretations offered here are tentative, and they require testing against additional data from both Kupgal and other sites in the region. Nonetheless, the interpretations that have been suggested are important because they demonstrate the utility of looking beyond 
rock art as images in order to take into account also its context within the wider physical and social landscape. Examined in such a way, rock art, despite the unintelligibility of the images themselves, can provide important insights into the internal dynamics of prehistoric societies. In this case, contextual analysis of the Kupgal Hill Neolithic rock art revealed a society in which pastoralism dominated, at least symbolically, and was associated with important rituals which likely invoked both social divisions and unities.

Finally, and perhaps most importantly, it is necessary to discuss not just the past, but also the present and the future of the Kupgal Hill rock art. No discussion of this site can today be considered complete if it does not also point out that the large-scale commercial granite quarrying that is currently underway at Kupgal and the surrounding area is simultaneously destroying some of the richest Neolithic remains in the world, including rock art. While the main rock art site is not threatened with immediate destruction, it is clearly only a matter of time before quarrying of granite in adjacent areas begins to have an impact on the site, as it already has at other rock art sites in both the immediate vicinity and wider region (Allchin 2003; Allchin \& Allchin 1994-95). Some of these, on both granite and dolerite, have been partially or even completely destroyed by quarrying activity.

That some of the rock art sites continue to hold meaning to groups living in the Sanganakallu-Kupgal area today indicates that this is not just a case of archaeologists against developers. For example, a previously unreported granitic rock shelter rich in microlithic remains and red-ochre pictographs to the north of Kupgal Hill (Boivin et al. 2002) is considered sacred by the Kurubas, a pastoral community who have settled in nearby Sirivaram village. The Kurubas regularly visit the site to worship the god Birappa, who is believed to reside in the shelter (Figure 6). The rock art on the outside of the shelter, some of which is possibly pre-Neolithic (i.e. Mesolithic) in date, was partially destroyed by

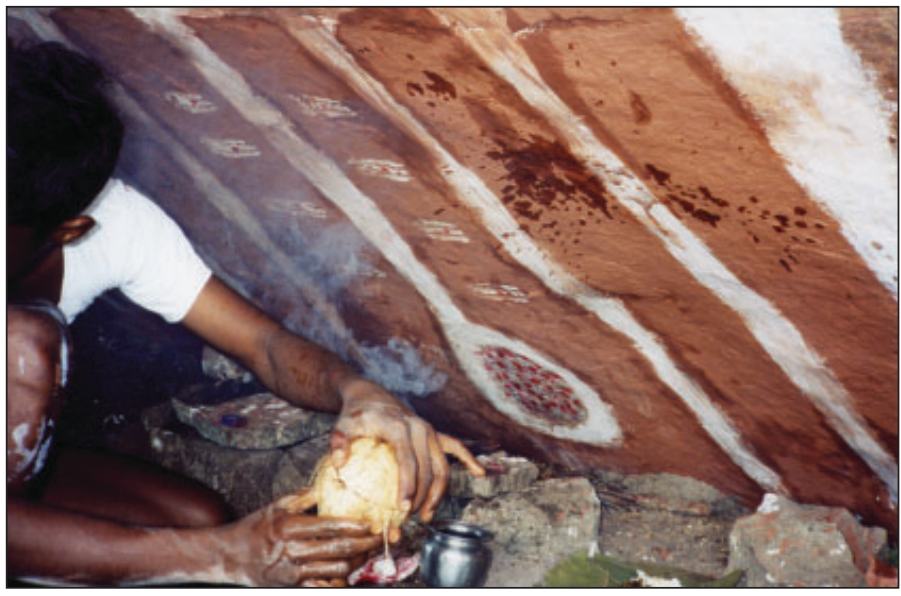

Figure 6 A ritual being performed inside the rock shelter near Kupgal Hill. Coconut milk has been splattered over top of the contemporary rock art motif in the background as part of the ritual.

quarrying, which was, however, halted before the entire shelter could be broken apart. A Kuruba informant told me that the men who came to quarry the stone had been scared away by a dangerous snake sent by Birappa to protect the site. It is unlikely, however, that largescale commercial quarrying of the type associated with the major granite outcrops would be impeded by such traditions, and it is clear that government intervention will be required to elicit effective protection for the majority of sites in the Sanganakallu-Kupgal area if these are not to be erased completely over the course of future years. 


\section{Rock art and rock music}

\section{Acknowledgements}

My 're-discovery' of the main Kupgal rock art site would have been difficult if not impossible without the assistance of Ramadas and Linganna, who were generous enough to take the time to show me this and other sites in the area. These two high school students from Sanganakallu village have spent years together exploring the Sanganakallu-Kupgal area and studying its prehistoric remains, and they possess a wealth of information on the archaeology of the area. I am also grateful for the assistance of my principal collaborators, Ravi Korisettar and P.C. Venkatasubbaiah, as well as those others who participated in the 2002 field season, including Helen Lewis, Deepak Havanur, Kalyan Malagyannavar, and Subhas Chincholi. Dr. Venkatasubbaiah's assistance in acquiring ethnographic information on the present-day use of prehistoric sites is much appreciated. I would additionally like to thank Andy Jones, Lise Myhoc, Michael Petraglia, Dave Robinson and Paul Taçon for providing encouragement and comments on a draft version of this paper, and Dorian Fuller for ongoing support and stimulating discussion. One anonymous reviewer is thanked for additional comments that helped improve the manuscript. Funding for the Sanganakallu-Kupgal project was provided by the British Academy, with additional aid coming from the Society for South Asian Studies, the Prehistoric Society and Karnatak University. More information about the Bellary District Archaeological Project can be found at http://www.mcdonald.cam.ac.uk/ Projects/bellary/index.html

\section{References}

Allchin, B. 2003. Cattle Pens, Hill Farmsteads, Rock Art: The Southern Neolithic. Paper presented at the Workshop on Recent Research on the South Indian Neolithic, McDonald Institute for Archaeological Research, Cambridge, Oct. 11.

Allchin, B. \& F.R. Allchin. 1982. The Rise of Civilisation in India and Pakistan. Cambridge: Cambridge University Press.

Allchin, F.R. 1960. Piklihal Excavations. Hyderabad: Government of Andhra Pradesh.

-1963. Neolithic Cattle-Keepers of South India. Cambridge: Cambridge University Press.

Allchin, F.R. \& B. Allchin. 1994-95. Rock art of North Karnataka. Bulletin of the Deccan College Post-Graduate and Research Institute 54-55: 313-39.

Bagwe, A. 1995. Of Women Caste: The Experience of Gender in Rural India. London: Zed Books.

BECK, B. 1964. Colour and heat in South Indian ritual, Man 4(4): 553-72.

BednariK, R.G. 1993. Palaeolithic art in India, Man and Environment 18(2): 33-40.

-2002. The development of Indian rock art studies since Independence. In S. Settar \& R. Korisettar (eds.), Indian Archaeology in Retrospect: Prehistory, Archaeology of South Asia: 353-75. Delhi: Manohar.

Borvin, N. 2000. Life rhythms and floor sequences: Excavating time in rural Rajasthan and Neolithic Çatalhöyük. World Archaeology. 31(3): 367-88.

-2001. 'Archaeological Science as Anthropology': Time, Space and Materiality in Rural India and the Ancient Past. Unpublished Ph.D. thesis, Department of Archaeology, University of Cambridge. -forthcoming. Landscape and cosmology in Neolithic South India.

Boivin, N. \& D Fuller. 2001. Looking for postprocessual theory in South Asian archaeology. In S. Settar \& R. Korisettar (eds.) Indian Archaeology in Retrospect, Volume IV: Archaeology and Historiography: 191-215. New Delhi: Manohar.

Boivin, N., R. Korisettar, \& P.C. Venkatasubbaiah. 2003. Megalithic markings in context: graffiti marks on burial pots from Kudatini, Karnataka. South Asian Studies 19: 1-12.

Boivin, N., R. Korisettar, P. C. Venkatasubbaiah, D. Havanur, K. Mallagyannavar \& S. Chincholi. forthcoming. Sarcophagus Burial at Kudatini, Karnataka.

Boivin, N., R. Korisettar, P.C. Venkatasubbaiah, H. Lewis, D. Havanur, K. Mallagyannavar \& S. Chincholi. 2002. Exploring Neolithic and Megalithic south India: the Bellary District Archaeological Project. Antiquity 76: 937-8.

BRADLEY, R. 1997. Rock art and the prehistory of Atlantic Europe. London: Routledge.

-2000. An Archaeology of Natural Places. London: Routledge.

Bradley, R. \& M. Edmonds. 1993. Interpreting the Stone Axe Trade: Production and Exchange in Neolithic Britain. Cambridge: Cambridge University Press.

Brooks, R. \& V.S. Wakankar. 1976. Stone Age Painting in India. New Haven: Yale University Press.

BurTon, J. 1984. Quarrying in a tribal society. World Archaeology 16(2): 234-47.

Chakrabarti, D.K. 1999. India, An Archaeological History: Palaeolithic Beginnings to Early Historic Foundations. New Delhi: Oxford. 


\section{Nicole Boivin}

Chakravarty, K.K. \& R. G. Bednarik. 1997. Indian Rock Art and its Global Context. Delhi: Motilal Banarasidass.

Chandramouli, N. 1991. Rock paintings of Budagavi, Anantapur District, Andhra Pradesh. Man and Environment 16(2): 71-80.

Chippindale, C. \& P.S.C. Taçon. (eds.) 1998. The Archaeology of Rock-Art. Cambridge: Cambridge University Press.

Devaraj, D.V., J.G. Shaffer, C.S. Patil \& Balasubramanya. 1995. The Watgal excavations: an interim report. Man and Environment 20(2): 57-74.

Dufresne, A.S., J.G. ShafFer, M.L Shivashankar $\&$ Balasubramanya. 1998. A preliminary analysis of microblades, blade cores and lunates from Watgal: A southern Neolithic site. Man and Environment 23(2): 17-43.

FAWCETT, F. 1892. Pre-Historic rock pictures near Bellary, South India. Imperial and Asiatic Quarterly Review (n.s.) 3: 147-57.

FoOTE, R.B. 1887 a. Notes on prehistoric finds in India. The Journal of the Anthropological Institute of Great Britain and Ireland 16: 70-75.

-1887 b. Notes on some recent Neolithic and Palaeolithic finds in South India. Journal of the Asiatic Society of Bengal 56(2): 259-82.

-1895 . The Geology of the Bellary District, Madras Presidency. The Memoirs of the Geological Survey of India 25(1): 1-216.

-1979. Prehistoric and Protohistoric Antiquities of India. Delhi: Leeladevi.

FULLER, D.Q. 1999. The Emergence of Agricultural Societies in South India: Botanical and Archaeological Perspectives. Unpublished Ph.D. Thesis, Department of Archaeology, University of Cambridge.

-in press. Domestication, diffusion and the development of agricultural villages: a study of the South Indian Neolithic. In K.R. van Kooij \& E.M. Ravern (eds.), South Asian Archaeology 1999. Leiden: Institute for Asian Studies.

-forthcoming. Dung mounds and domesticators: Early cultivation and pastoralism in Karnataka. In C. Jarrige (ed.), South Asian Archaeology 2001.

Fuller, D. \& N. Boivin. 2001. Beyond description and diffusion: A history of processual theory in the archaeology of South Asia. In S. Settar \& R. Korisettar (eds.), Indian Archaeology in Retrospect, Volume IV: Archaeology and Historiography: 161-90. New Delhi: Manohar.

Fuller, D.Q., R. Korisettar \& P.C. Venkatasubbaiah. 2001. Southern Neolithic cultivation systems: a reconstruction based on archaeobotanical evidence. South Asian Studies 17: 171-87.
Fuller, D.Q., P.C Venkatasubbaiah \& R. Korisettar. 2000-2001. The beginning of agriculture in the Kundera River Basin: Evidence from archaeological survey and archaeobotany. Puratattva 31: 1-8.

Ganapayya BHAT, P. 1981. Rock art of Karnataka. Man in India 61(1): 46-54.

Gero, J.M. 1991. Genderlithics: Women's roles in stone tool production. In J.M.Gero \& M.W. Conkey (eds.), Engendering Archaeology: Women and Prehistory: 163-93. Oxford: Blackwell.

Goldhahn, J. (ed.) 1999. Rock Art as Social Representation. Bar International Series 794. Oxford: Archaeopress.

-2002. Roaring rocks: an audio-visual perspective on hunter-gatherer engravings in Northern Sweden and Scandinavia. Norwegian Archaeological Review 35(1): 29-61.

Gordon, D.H. 1951. The rock engravings of Kupgallu Hill, Bellary, Madras. Man 51: 117-19.

Gordon, D.H. \& F.R. Allchin. 1955. Rock paintings and engravings in Raichur, Hyderabad. Man 55: 97-99.

Hedges, K. 1993. Places to see and places to hear: rock art and features of the sacred landscape. In J. Steinbring, A. Watchman, P. Faulstich \& P. Taçon (eds.), Time and Space: Dating and Spatial Considerations in Rock Art Research: 121-27. Melbourne: Australian Rock Art Research Association. Occasional AURA Publication No. 8.

Helskog, K. \& B. Olsen. (eds.) 1995. Perceiving Rock Art: Social and Political Perspectives. Oslo: Institute for Comparative Research in Human Culture.

HuYler, S. 1994. Creating sacred spaces: women's wall and floor decorations in Indian Homes. In N. Fisher (ed.), Mud, Mirror and Thread: Folk Traditions of Rural India: 172-91. Ahmedabad: Mapin.

Jones, R. \& N. White. 1988. Point blank: stone tool manufacture at the Ngilipitji Quarry, Arnhem Land, 1981. In B. Meehan \& R. Jones (eds.), Archaeology with Ethnography: An Australian Perspective: 51-87. Canberra: Australian National University.

Korisettar, R., P.P. Joglekar, D.Q. Fuller \& P.C. VenKatasubBaiah. 2001. Archaeological reinvestigation and archaeozoology of seven southern Neolithic sites in Karnataka and Andhra Pradesh. Man and Environment 26(2): 47-66.

Korisettar, R., P.C. Venkatasubbaiah \& D.Q. Fuller. 2001. Brahmagiri and beyond: The archaeology of the southern Neolithic. In S. Settar \& R. Korisettar (eds.), Indian Archaeology in Retrospect, Volume 1: Prehistory, Archaeology of South Asia: 151-237. New Delhi: Manohar. 


\section{Rock art and rock music}

LESLIE, J. 1991. Sri and Jyestha: ambivalent role models for women. In J. Leslie (ed.), Roles and Rituals for Hindu Women: 107-27. London: Pinter.

Mujumdar, G.G. \& S.N. Rajaguru. 1966. Ashmound Excavations at Kupgal. Poona: Deccan College.

Milne, C. 1995. Sacred Places in North America: A Journey into the Medicine Wheel. New York: Stewart, Tabori \& Chang.

Nagaraja Rao, M.S. \& K.C. Malhotra. 1965. The Stone Age Hill Dwellers of Tekkalakota. Poona: Deccan College.

Nagarajan, V. 1995. Hosting the divine: the kolam in Tamilnadu. In N. Fisher (ed.), Mud, Mirror and Thread: Folk Traditions in Rural India: 192-224. Ahmedabad: Mapin.

Needham, R. 1967. Percussion and transition. Man 2: 606-14.

Neumayer, E. 1983. Prehistoric Indian Rock Paintings. Delhi: Oxford University Press.

O'Flaherty, W.D. (trans.) 1994. The Rig Veda. New Delhi: Penguin.

Ouzman, S. 1998. Towards a mindscape of landscape: rock-art as expression of world-understanding. In C. Chippindale \& P.S.C. Taçon (eds.), The Archaeology of Rock-Art: 30-41. Cambridge: Cambridge University Press.

-2001 . Seeing is deceiving: rock art and the non-visual. World Archaeology 33(2): 237-56.

PADDAYYA, K. 1973. Investigations into the Neolithic culture of the Shorapur Doab, South India. Leiden: E.J. Brill.

-1993. Ashmound investigations at Budihal, Gulbarga District, Karnataka. Man and Environment 18: 57-87.

-1998. Evidence of Neolithic cattle-penning at Budihal, Gulbarga District, Karnataka. South Asian Studies 14: 141-153.

Paddayya, K, P.K. Thomas \& P.P. JogleKar. 1995. A Neolithic butchering floor from Budihal, Gulbarga District, Karnataka. Man and Environment 20(2): 23-31.

PiggotT, S. 1950. Prehistoric India. Harmondsworth: Penguin.

RAINBIRD, P. 2002a. Making sense of petroglyphs: the sound of rock art. In B. David \& M. Wilson (eds.), Inscribed Landscapes: Marking and Making Place: $93-$ 103. Honolulu: University of Hawaii Press. -2002b. Marking the body, marking the land - body as history, land as history: tattooing and engraving in Oceania. In Y. Hamilakis, M. Pluciennik \& S. Tarlow (eds.), Thinking Through the Body: Archaeologies of Corporeality: 233-47. New York: Plenum.

RAMI REDDY, V. 1971. Rock paintings and bruisings in Andhra Pradesh. The Eastern Anthropologist 24(3): 289-96.

SASSAMAN, K.E. 1998. Lithic technology and the hunter-gatherer sexual division of labour. In K. Hays-Gilpin \& D.S. Whitley (eds.), Reader in Gender Archaeology: 159-71. London: Routledge.

SCARre, C. 1989. Painting by resonance. Nature 338: 382.

Settar, S. \& G.D. Sontheimer. (eds.) 1982. Memorial Stones: A Study of Their Origin, Significance and Variety. Dharwad: Institute of Indian Art History, and Heidelberg: South Asia Institute.

Sillitoe, P. \& K. Hardy. 2003. Living lithics: ethnoarchaeology in Highland Papua New Guinea. Antiquity 77: 555-66.

SubBarao, B. 1947. Archaeological explorations in Bellary. Bulletin of the Deccan College Research Institute 8: 209-24.

-1948. Stone Age Cultures of Bellary. Poona: Deccan College.

TAÇON, P.S.C. 1990. The power of place: cross-cultural responses to natural and cultural landscapes of stone and earth. In J.M. Vastokas, J. Paper \& P.S.C. Taçon (eds.), Perspectives of Canadian Landscape: Native Traditions: 11-43. York University (Ont.): Robarts Centre for Canadian Studies.

-1991 . The power of stone: symbolic aspects of stone use and tool development in western Arnhem Land, Australia. Antiquity 65: 192-207.

THAPAR, R. 1981. Death and the hero, in S.C. Humphreys \& H. King (eds.), Mortality and Immortality: The Anthropology and Archaeology of Death, 293-315. London: Academic Press.

Tuzin, D. 1984. Miraculous voices: the auditory experience of numinous objects. Current Anthropology 25(5): 579-96.

Whitley, D.S. (ed.) 2001. Handbook of Rock Art Research. Oxford: Altamira.

ZEUNER, F.E. 1960. On the origin of the cinder mounds of the Bellary district, India. Bulletin of the Institute of Archaeology 2: 37-44. 